\title{
Metformin alters therapeutic effects in the BALB/c tumor therapy model
}

\author{
Felix B. Meyer, Sophie Goebel, Sonja B. Spangel, Christiane Leovsky, Doerte Hoelzer and René Thierbach
}

\begin{abstract}
Background: Despite considerable medical proceedings, cancer is still a leading cause of death. Major problems for tumor therapy are chemoresistance as well as toxic side effects. In recent years, the additional treatment with the antidiabetic drug metformin during chemotherapy showed promising results in some cases. The aim of this study was to develop an in vitro tumor therapy model in order to further investigate the potential of a combined chemotherapy with metformin.

Methods: Cytotoxic effects of a combined treatment on BALB/c fibroblasts were proven by the resazurin assay. Based on the BALB/c cell transformation assay, the BALB/C tumor therapy model was established successfully with four different and widely used chemotherapeutics from different categories. Namely, Doxorubicin as a type-II isomerase inhibitor, Docetaxel as a spindle toxin, Mitomycin C as an alkylating agent and 5-Fluorouracil as an antimetabolite. Moreover, glucose consumption in the medium supernatant was measured and protein expressions were determined by Western Blotting.

Results: Initial tests for the combined treatment with metformin indicated unexpected results as metformin could partly mitigate the cytotoxic effects of the chemotherapeutic agents. These results were further confirmed as metformin induced resistance to some of the drugs when applied simultaneously in the tumor therapy model. Mechanistically, an increased glucose consumption was observed in non-transformed cells as well as in the mixed population of malignant transformed cell foci and non-transformed monolayer cells, suggesting that metformin could also increase glucose consumption in transformed cells.
\end{abstract}

Conclusion: In conclusion, this study suggests a cautious use of metformin during chemotherapy. Moreover, the BALB/c tumor therapy model offers a potent tool for further mechanistic studies of drug-drug interactions during cancer therapy.

Keywords: Metformin, Cancer, In vitro model, Adjuvant, Energy metabolism

\section{Background}

Worldwide, cancer is one of the leading causes of death with estimated 9.6 million deaths in 2018 [1]. Due to medical proceedings, the survival rates are increasing but chemoresistance and toxic side effects are still major problems for chemotherapy. Thereby, the combined treatment of chemotherapeutics with several substances seems to be a

\footnotetext{
* Correspondence: rene.thierbach@uni-jena.de

Friedrich-Schiller-Universität Jena, Fakultät für Biowissenschaften, Institut für Ernährungswissenschaften, Abteilung Humanernährung, Jena, Germany
}

promising approach [2]. In 2005, it was demonstrated for the first time that diabetic patients taking the widely used antidiabetic drug metformin show lower incidences for developing cancer [3]. Since then, the anticancer effects of metformin got into the focus of cancer research.

Molecularly, metformin inhibits the mitochondrial complex I following an increase in the ATP:AMP ratio that finally leads to an activation of the cellular energy sensor $5^{\prime}$ AMP-activated protein kinase (AMPK) [4]. As a result, metformin reduces blood glucose levels systemically via AMPK-mediated inhibition of hepatic gluconeogenesis

(c) The Author(s). 2021 Open Access This article is licensed under a Creative Commons Attribution 4.0 International License, which permits use, sharing, adaptation, distribution and reproduction in any medium or format, as long as you give appropriate credit to the original author(s) and the source, provide a link to the Creative Commons licence, and indicate if changes were made. The images or other third party material in this article are included in the article's Creative Commons licence, unless indicated otherwise in a credit line to the material. If material is not included in the article's Creative Commons licence and your intended use is not permitted by statutory regulation or exceeds the permitted use, you will need to obtain permission directly from the copyright holder. To view a copy of this licence, visit http://creativecommons.org/licenses/by/4.0/ The Creative Commons Public Domain Dedication waiver (http://creativecommons.org/publicdomain/zero/1.0/) applies to the data made available in this article, unless otherwise stated in a credit line to the data. 
[5-7] and an increased glucose uptake in peripheral tissues $[8,9]$, both leading to lower insulin levels consequently. This could partly explain the anticancer effects of metformin, since increased glucose and insulin levels are associated with cancer proliferation and mortality $[10,11]$.

In addition, metformin exerts direct effects on cancer cells and is able to reduce glucose consumption via reversion of the Warburg effect in several tumor cell lines independent of AMPK [12-16]. Therefore, metformin is discussed as an adjuvant in tumor therapy in diabetic and non-diabetic patients with promising results especially for colorectal and prostate cancer $[17,18]$. For the use of several chemotherapeutic agents, toxic side effects are a doselimiting factor that could also be improved by metformin. For example, the cardiotoxicity of Doxorubicin (Dox) is reduced when the treatment is combined with metformin [19]. Moreover, metformin could enhance the effectiveness of Docetaxel (Dtx) in hyperglycemic conditions [20], suggesting its promising role for cancer treatment in patients with diabetes.

Even though several anticarcinogenic effects of metformin are observed, the clinical data are still contentious depending on disease-related (type of tumor, clinical stage, form of treatment) and on patient-related factors (insulin resistance, age, sex) [21]. For in vitro experiments, the combination of metformin with several chemotherapeutic agents shows controversial results ranging from synergistic effects [22-24] to even adverse effects [25, 26]. So far, these investigations underline the need for a more detailed understanding of the molecular mechanisms that occur when combining metformin with chemotherapeutics before applying it as a potential adjuvant in chemotherapy.

A helpful tool could be the BALB/c cell transformation assay (BALB-CTA) which mimics different phases of malignant cell transformation in vitro and is eligible for mechanistic cancer research [27]. With an additional treatment during the assay, the potential effects of different chemotherapeutic agents can be investigated and molecular mechanisms further analyzed [28]. In the present study, we intended to establish a BALB/C tumor therapy model (BALB-TTM) using commonly applied chemotherapeutic agents. Thereby, the treatment was conducted during the late phase of malignant cell transformation on already existing cell foci. In a second step, the combined therapy of metformin with the chemotherapeutic agents was tested. Thus, the BALB-TTM could be a strong tool for clarifying molecular mechanisms of drug-drug interactions and the development of more effective chemotherapies.

\section{Methods}

\section{Cell culture}

BALB/c-3 T3-A31-1-1 cells from Hatano Research Institute of Japan were kindly provided by Dr. A. Poth (Harlan Cytotest Cell Research GmbH, Roßdorf) and used for all of the experiments. Cells were cultivated with DMEM/ HAM's F-12 (Biochrom \#T481) containing $3.15 \mathrm{~g} / \mathrm{l}$ Dglucose, $5 \%$ fetal bovine serum and $1 \%$ penicillin/streptomycin in an incubator $\left(37^{\circ} \mathrm{C}, 5 \% \mathrm{CO}_{2}, 95 \%\right.$ humidity). Only subconfluent grown cells (70 to $80 \%$ confluence) between the passages 20 to 45 were used. Tests for mycoplasmas were conducted regularly and were negative.

\section{Cell viability assay}

The indicator dye alamarBlue ${ }^{\bullet}$ (Bio-Rad \#BUF012) was used to determine cell viability. Cells were seeded in 96 well plates $(15,000$ per well) and allowed to grow confluent for $48 \mathrm{~h}$. Afterwards, cells were treated for $24 \mathrm{~h}$ with the chemotherapeutics, metformin or a combination of both. In every treatment group, the DMSO concentration was adapted to a constant level of $0.1 \%$. Finally, medium was discarded and non-fluorescent alamarBlue containing medium (ratio 1:10) was added. Fluorescence signal was measured after $0 \mathrm{~h}$ (blank) and $3 \mathrm{~h}$ (Ex $540 \mathrm{~nm} / \mathrm{Em} 590$ $\mathrm{nm})$. Thereby, the reduction of non-fluorescent resazurin to fluorescent resorufin is proportional to cell viability. The cell viability assay was performed with 6 technical replicates for the single treatment and with 3 technical replicates for the combination therapy in 3 biological replicates, respectively.

\section{BALB/c cell transformation assay}

The BALB-CTA was performed according to the recommended protocol of the European Centre for the Validation of Alternative Methods [29]. Differing from this protocol, cells were cultivated for the whole time in DMEM/HAM's F-12 medium and the duration of the assay was prolonged to 42 days. On the first day, 5000 cells per well were seeded in Corning ${ }^{\oplus}$ Primaria $^{\text {ma }}$ 6-well-plates (Corning \#353846) and cultivated under standard conditions. Change of medium was performed twice a week. Malignant cell transformation was induced by treatment with the tumor initiator 3methylcholanthrene (MCA, Sigma \#213942) $(0.5 \mu \mathrm{g} / \mathrm{ml}$, dissolved in DMSO) from day 1-4 following the tumor promotor 12-tetradecanoylphorbol-13-acetate (TPA, Sigma \#79346) $(0.3 \mu \mathrm{g} / \mathrm{ml}$, dissolved in DMSO) from day 8-21. Consequently, cells lose their contact inhibition and start to grow over the monolayer and as a result, characteristic cell foci of transformed cells are formed. An additional treatment was conducted either chronically from day 1-42 or therapeutically from day 32-42 with metformin (for details see Fig. 2a). On day 42, cells were washed twice with cold $\left(4{ }^{\circ} \mathrm{C}\right)$ PBS and fixed with cold PBS/methanol (ratio 1:1) for 3 min following treatment with ice cold methanol $\left(-20^{\circ} \mathrm{C}\right)$ for $10 \mathrm{~min}$. Finally, cells were washed twice with ice cold methanol and dried at room temperature. For better visualization of cell foci, cells were stained with Giemsa solution (AppliChem \#251338). Per well, $1 \mathrm{ml}$ Giemsa solution was added, incubated for $3 \mathrm{~min}$ and afterwards diluted 
with $3 \mathrm{ml}$ of deionized water and incubated for further 3 min. The whole solution was discarded and cells were washed 5 times with tap water following $5 \times 10 \mathrm{~min}$ washing with deionized water on the plate shaker.

In order to establish the BALB-TTM, cells were treated from day 32-35 with the chemotherapeutics Doxorubicin (Cayman \#15007, dissolved in DMSO), Docetaxel (Cayman \#11637, dissolved in DMSO), Mitomycin C (Fisher Scientific \#10182953, dissolved in DMSO), 5-Fluorouracil (Sigma-Aldrich \#F6627, dissolved in DMSO), the antidiabetic drug metformin (Sigma-Aldrich \#PHR1084, dissolved in water) or with the chemotherapeutics in combination with metformin. Due to the high potency of the chemotherapeutic drugs, cells were fixed already on day 35 . For all experiments, DMSO served as a solvent control and was adapted to a constant concentration of $0.05 \%$ from day $1-32$. The treatment with the chemotherapeutics on day 32-35 increased the DMSO concentration that was now kept constant at $0.1 \%$. Unless stated otherwise, the assays were performed with 4 technical replicates in 4 biological experiments. The number of type-III foci was counted independently by 2 different people as described elsewhere [30].

\section{Glucose measurement}

Glucose concentration was determined in medium supernatant using medium without phenol red. Cells were seeded in $10 \mathrm{~cm}$ cell culture dishes $(600,000$ cells/ dish) and allowed to grow confluent for $72 \mathrm{~h}$. Cell monolayer was treated with $1 \mathrm{mM}$ and $10 \mathrm{mM}$ metformin and $1 \mathrm{ml}$ of cell culture supernatant was collected after 0,24 , 48, 72 and 96 h. Samples were diluted $1: 15$ or $1: 45$ with deionized water. Standard series with 0, 10, 20, 40, 60 and $80 \mu \mathrm{g} / \mathrm{ml}$ was generated with deionized water and D-Glucose solution (Sigma-Aldrich \#G3285). One capsule of glucose oxidase/peroxidase reagent (Sigma-Aldrich \#G3660) was solved in $39.2 \mathrm{ml}$ deionized water and a stock solution with $5 \mathrm{mg} / \mathrm{ml}$ of o-dianisidine dihydrochloride (Sigma-Aldrich \#F5803) was prepared. Finally, the two components were mixed in the ratio 1:50 in order to generate the assay reagent. Probes and standards were pipetted in quadruples on a 96 well plate $(60 \mu \mathrm{l} /$ well), the assay reagent was added $(120 \mu \mathrm{l} /$ well $)$ and incubated for $30 \mathrm{~min}$ at $37^{\circ} \mathrm{C}$. The oxidation of glucose to gluconic acid via the glucose oxidase generates hydrogen peroxides that further react with o-dianisidine in presence of the peroxidase to form a brown colored product. By adding $120 \mu \mathrm{l} /$ well $6 \mathrm{M}$ sulfuric acid (Carl Roth \#4623.1) the reaction stops and a stable pink colored product is formed. The intensity of the pink color can be measured at $540 \mathrm{~nm}$ and is proportional to the initial glucose concentration. Glucose measurement was conducted in 3 biological replicates.

\section{Protein extraction and immunoblot}

Cells were harvested with cell lysis buffer (Cell Signaling \#9803) and sonicated (UP200S, Hielscher Ultrasonics $\mathrm{GmbH}$ ) afterwards. Proteins were isolated after centrifugation and concentration was determined according to the Bradford method [31]. SDS-PAGE was performed with a $10 \%$ gel using $30 \mu \mathrm{g}$ protein per lane. Proteins were transferred on a nitrocellulose membrane with the semi-dry Western Blot and incubated with phosphoAMPK (Cell Signaling \#2535), AMPK (Cell Signaling \#2532) or $\alpha$-Tubulin (Sigma Aldrich \#T9026) following the secondary antibodies anti-Rabbit (Cell Signaling \#7074) or anti-Mouse (Cell Signaling \#7076).

\section{Statistical analysis}

The software IBM SPSS was used for all statistical analyses. The results were tested for homogeneity of variances each and as described elsewhere [32, 33], the normal distribution was neglected. For the cell viability assay, a one-way ANOVA was performed following the Dunnett- T post-hoc test in case of homogeneity of variances or the Dunnett-T3 if this was not the case. Statistical differences of the type-III foci in the BALB-TTM and the glucose concentration in the medium were calculated for existing homogeneity of variances with a one-way ANOVA and an additional Bonferroni post-hoc test. Otherwise, a Dunnett-T3 post-hoc test was performed.

Positive or negative drug combination effects were further described with the Highest Single Agent approach [34]. According to that, the Combination Index (CI) was calculated as following, with $\max \left(\mathrm{E}_{\mathrm{A}}, \mathrm{E}_{\mathrm{B}}\right)$ describing the effect of the highest concentration of the single agent and $\mathrm{E}_{\mathrm{AB}}$ for the effect for the combination treatment:

$$
C I=\frac{\max \left(E_{A}, E_{B}\right)}{E_{A B}}
$$

Hence, the CI gives information whether the combination of two components shows greater $(\mathrm{CI}>1)$ or smaller effects $(\mathrm{CI}<1)$ compared to a single agent alone.

\section{Results \\ Metformin affects glucose consumption in non- transformed BALB/c cells}

A potential influence of metformin on energy metabolism was investigated first. In control cells, the glucose concentration decreased steadily from $3.15 \mathrm{~g} / \mathrm{l}$ reaching $2.2 \mathrm{~g} / \mathrm{l}$ after $96 \mathrm{~h}$. Metformin increases glucose consumption significantly and dose-dependently. After $24 \mathrm{~h}$ treatment, glucose concentration was already at 2.4 and 2.2 $\mathrm{g} / \mathrm{l}$ for 1 and $10 \mathrm{mM}$ metformin, respectively. Incubation with metformin for $96 \mathrm{~h}$ leads to glucose concentrations of 1.1 and $0.4 \mathrm{~g} / \mathrm{l}$ for 1 and $10 \mathrm{mM}$ (Fig. 1a). 


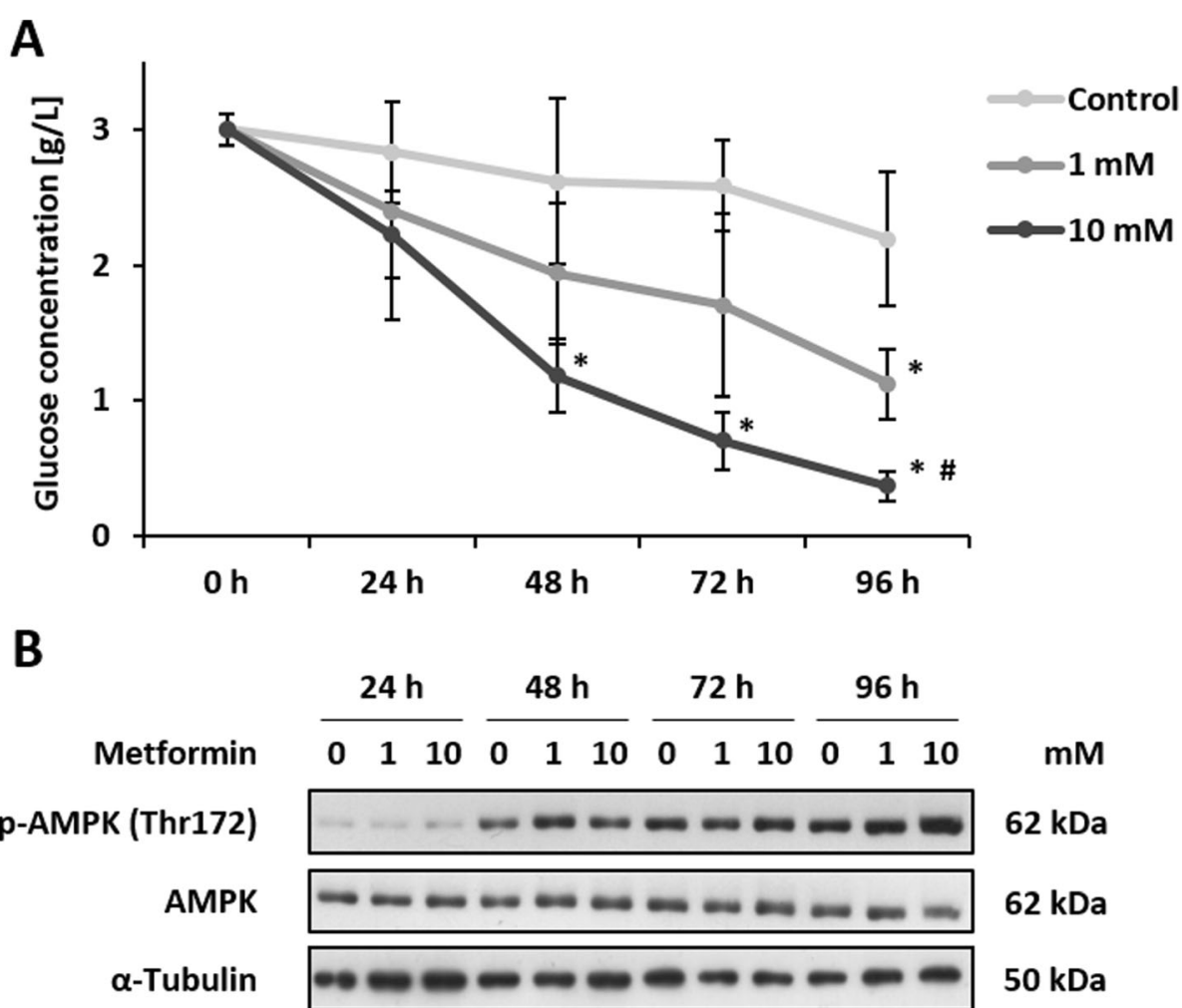

Fig. 1 Altered energy metabolism after metformin treatment. Non-transformed BALB/c cells were seeded in $10 \mathrm{~cm}$ cell culture dishes and allowed to grow confluent for $72 \mathrm{~h}$. Afterwards, cells were treated with 1 or $10 \mathrm{mM}$ metformin. Medium supernatant was collected after 0, 24, 48, 72 and $96 \mathrm{~h}$ and cells were harvested for protein analysis. a Glucose concentration was measured and data are shown as mean + SD of 3 biological replicates. Statistical differences were calculated with a one-way ANOVA (post-hoc: Bonferroni or Dunnett-T3) with * $=(p<0.05)$ vs. control and \# = ( $p<0.05)$ vs. $1 \mathrm{mM}$ metformin for each point in time. $\mathbf{b}$ Proteins were extracted and protein expression as well as phosphorylation levels of AMPK at Thr172 were detected via immunoblot in 3 biological replicates. After detection of p-AMPK, the membrane was stripped two times and re-probed with AMPK mAB and a-Tubulin mAB to confirm equal loading. Images shown are cropped from fulllength blots represented in Additional file 2: Supplementary Figure 2

Phosphorylation levels of AMPK increased over time but interestingly, metformin showed no consistent effect on both, phosphorylation and expression of AMPK (Fig. 1b). However, the densitometric analysis indicates an increased phosphorylation level of AMPK after the treatment with $10 \mathrm{mM}$ metformin for $96 \mathrm{~h}$ associated with a lower protein level of AMPK (Additional file 1: Supplementary Figure 1). This could be due to a lack of nutrients, especially glucose.

\section{Anticarcinogenic effects of metformin in the BALB-CTA}

In order to study the effects of metformin on malignant cell transformation, a BALB-CTA was performed as described earlier [27, 28] (Fig. 2a). Permanent treatment (day 1-42) with $1 \mathrm{mM}$ metformin showed anticarcinogenic effects and decreased the number of type-III foci significantly by $32 \%$ while lower concentrations had no effect. Furthermore, we also observed an effect when 1 $\mathrm{mM}$ metformin was added for a shorter duration from day 32 until day 42 on the cell monolayer with already existing cell foci as the number of type-III foci decreased by $70 \%$ (Fig. 2 b).

Establishment of the BALB/c tumor therapy model (BALBTTM)

Because treatment in the late phase of the BALB-CTA is comparable to a therapeutic usage, we asked whether the BALB-CTA is suitable for therapy questions in general. Therefore, the applicability of a BALB-TTM was tested by using chemotherapeutic agents with different mode of actions. Namely, Dox as a type-II isomerase inhibitor, Mitomycin C (MMC) as an alkylating agent, 5Fluorouracil (5-FU) as an antimetabolite and Dtx as a spindle toxin. Suitable concentrations were determined prior with the Resazurin cell viability assay on nontransformed BALB/c cells. Cell viability was decreased significantly after treatment with $183 \mathrm{nM}$ Dox by $12 \%$ (Fig. 3a), $62 \mathrm{nM}$ Dtx by $17 \%$ (Fig. 3b) and $5 \mu \mathrm{M}$ MMC by 16\% (Fig. 3c). 5-FU showed no cytotoxic effects at a concentration up to $100 \mu \mathrm{M}$ (Fig. 3d). For the BALB-TTM establishment, a BALB-CTA was performed with 


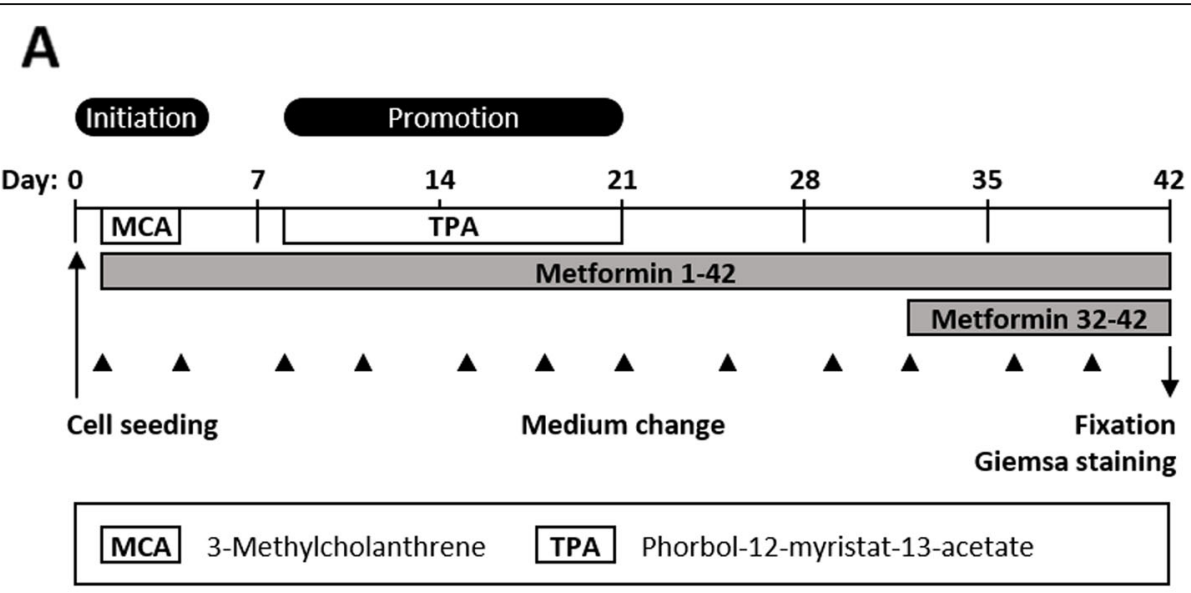

B

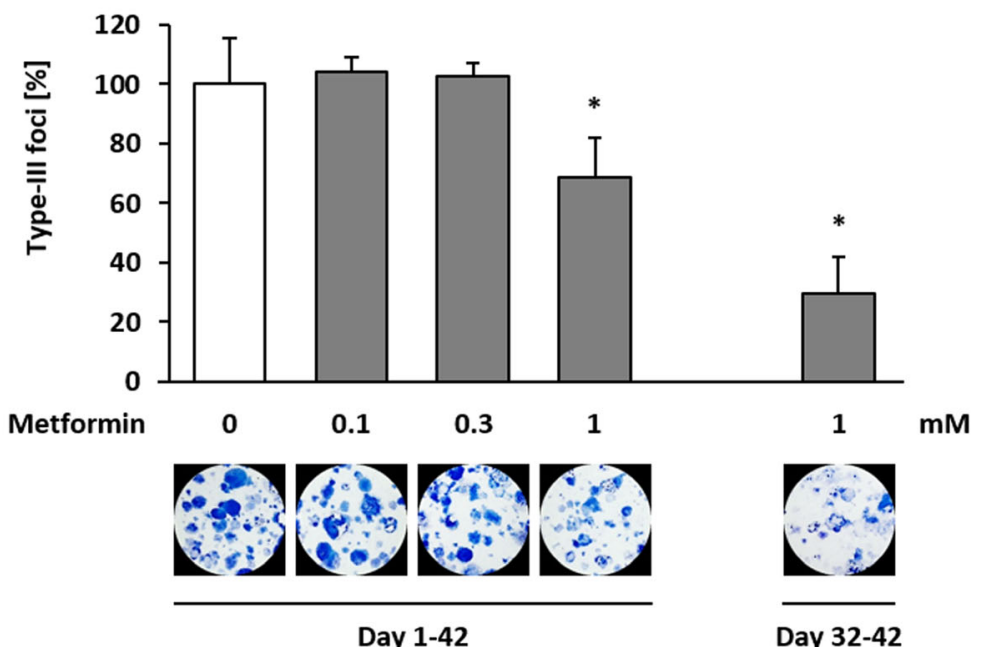

Fig. 2 Anti-carcinogenic effect of Metformin in the BALB-CTA. a The BALB/C 3 T3 cell transformation assay was performed according to the recommended protocol. In brief, cells were seeded in 6-well plates and treated with the tumor initiator $\mathrm{MCA}(0.5 \mu \mathrm{g} / \mathrm{ml})$ on day $1-4$ and the tumor promotor TPA $(0.3 \mu \mathrm{g} / \mathrm{ml})$ from day $8-21$ in order to induce malignant cell transformation. Metformin was added additionally either chronical from day 1-42 or in the late phase of malignant cell transformation from day $32-42$. On day 42 , cells were fixed with methanol and stained with Giemsa solution for better visualization of cell foci. $\mathbf{b}$ Representative pictures and the number of type-III foci of 3 biological replicates $($ mean + SD) are shown. Statistical differences were calculated with a one-way ANOVA (post-hoc: Bonferroni) with $*=(p<0.05)$ vs. control

following modifications. Because of the high potency of the chemotherapeutic drugs, the therapeutic treatment was shortened to $72 \mathrm{~h}$ from day 32 to 35 (Fig. 4a). After the treatment in the late phase of malignant cell transformation, a significantly reduced number of type-III foci was observed for all of the tested chemotherapeutic agents. With the exception of Dox (Fig. 4b), this was even the case for non-toxic concentrations, namely 12.4 nM Dtx (Fig. 4c), $1 \mu \mathrm{M}$ MMC (Fig. 4d) and $10 \mu \mathrm{M} 5-\mathrm{FU}$ (Fig. 4e).

\section{Effects of chemotherapeutic agents plus metformin on non-transformed cells}

In order to get suitable concentrations for the combined therapy with metformin plus chemotherapeutic agents in the BALB-TTM, the cell viability of non-transformed $\mathrm{BALB} / \mathrm{c}$ cells was measured. The single treatment with $0.1,1$ and $10 \mathrm{mM}$ metformin had no impact on cell viability (Fig. 5a-d). Up to $100 \mathrm{nM}$ Dox showed no effects on cell viability but it was decreased significantly after the combined treatment with $100 \mathrm{nM}$ Dox plus $0.1 \mathrm{mM}$ metformin by $14 \%(\mathrm{CI}=1.06)$, plus $1 \mathrm{mM}$ metformin by $10 \%(\mathrm{CI}=1.01)$ and plus $10 \mathrm{mM}$ metformin by $10 \%(\mathrm{CI}=$ 1.02), respectively (Fig. 5a). Dtx led to a significant decrease in cell viability at a concentration of $10 \mathrm{nM}$ by $19 \%$. However, the supplementary treatment with 10 $\mathrm{mM}$ metformin abolished this effect. Thus, the observed decrease in cell viability was only at $9 \%(\mathrm{CI}=0.89)$ (Fig. $5 \mathrm{~b}$ ), meaning that metformin seems to protect the cells. A cytotoxic effect for MMC was detected at a 

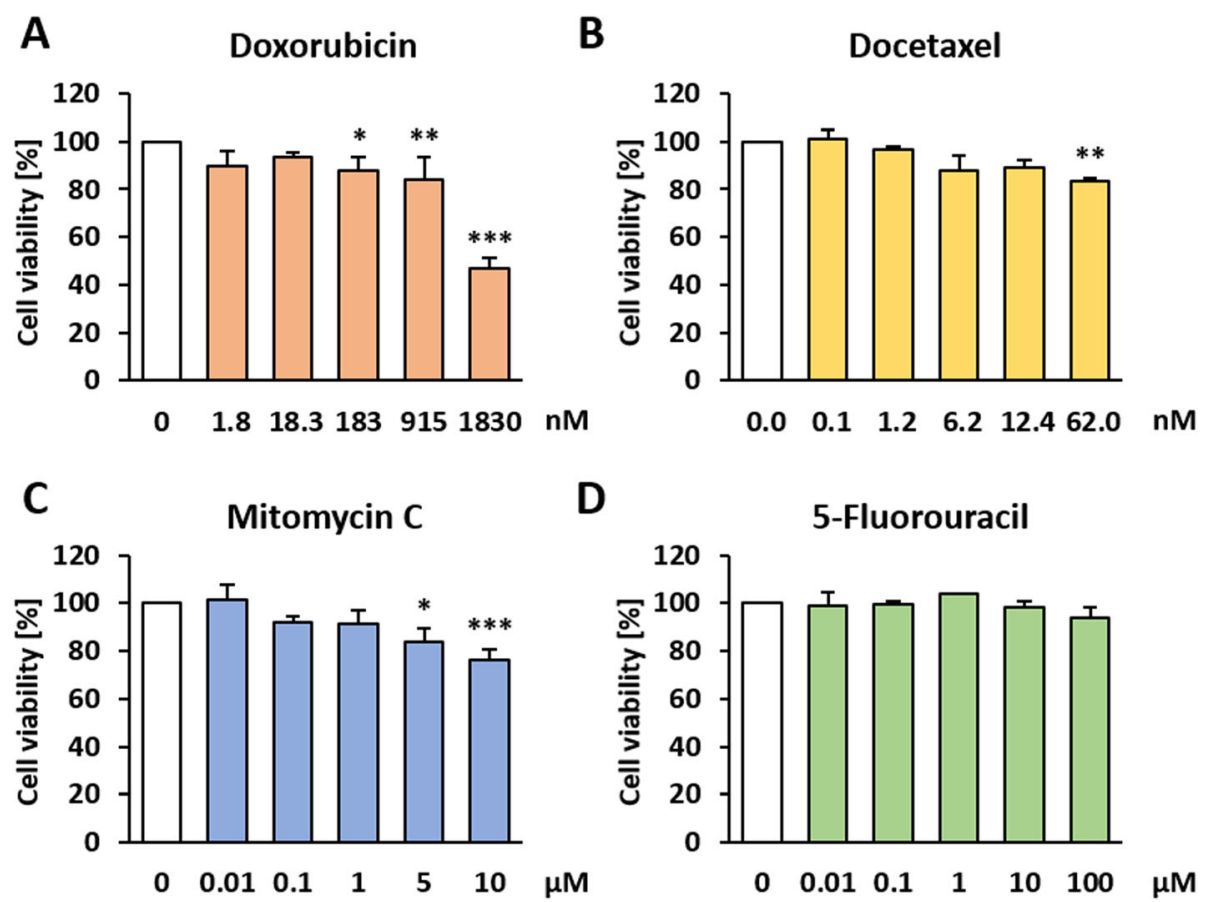

Fig. 3 Cytotoxic effects of chemotherapeutics on BALB/C cells. Non-transformed BALB/c cells were seeded in 96 well plates and allowed to grow confluent for $48 \mathrm{~h}$. Afterwards, cells were treated for $24 \mathrm{~h}$ with different concentrations of a Doxorubicin, b Docetaxel, c Mitomycin C or d 5Fluorouracil. Cell viability was measured indirectly by the reduction of resazurin to fluorescent resorufin. Data are shown as mean + SD of 3 biological replicates. Statistical differences were calculated with a one-way ANOVA (post-hoc: two sided Dunnett-T or Dunnett-T3) with ${ }^{*}=(p<$ $0.05) ;{ }^{* *}=(p<0.01)$ and ${ }^{* * *}=(p<0.001)$ vs. control

concentration of $10 \mu \mathrm{M}$, decreasing cell viability by $27 \%$. The additional treatment with $10 \mathrm{mM}$ metformin increased cell viability significantly $(\mathrm{CI}=0.85)$ but was still cytotoxic with a decrease in cell viability by $15 \%$ (Fig. 5c). Neither the single treatment with 5-FU nor the combination with metformin showed any effect on cell viability (Fig. 5d).

\section{Combined treatment in the BALB-TTM}

The effectiveness of a combined therapy with chemotherapeutic agents plus metformin was tested in the BALB-TTM (Fig. 6a). For all chemotherapeutics, two concentrations were chosen and tested alone or in combination with $1 \mathrm{mM}$ metformin. According to the preliminary tests, the lower concentration should not reduce number of type-III foci and the higher concentration reduces it significantly. Treatment with $1 \mathrm{mM}$ metformin alone in the BALB-TTM decreased number of type-III foci up to $27 \%$ but this effect was not significant (Fig. 6b-e). For Dox, a therapeutic effect was observed only with the toxic concentrations of $183 \mathrm{nM}$ and 915 nM (Fig. 4b). Therefore, 1 and $10 \mathrm{nM}$ Dox, which show no significant effect on type-III foci, were combined with metformin. Compared to the single treatments with the chemotherapeutics, the co-treatment increased the number of type-III foci by $14 \%(\mathrm{CI}=0.86)$ and $18 \%(\mathrm{CI}=$
0.78) but this effect was not significant (Fig. 6b). The lower concentration of $1 \mathrm{nM}$ Dtx showed no therapeutic effect in the BALB-TTM and $10 \mathrm{nM}$ reduced number of type-III foci significantly by $48 \%$. However, the combination with metformin neglected this effect, meaning that $10 \mathrm{nM}$ Dtx plus $1 \mathrm{mM}$ metformin showed a $12 \%$ smaller and no significant decrease in the number of type-IIIfoci $(\mathrm{CI}=0.82$ ) (Fig. 6c). For MMC and 5-FU, the lower concentrations of $0.1 \mu \mathrm{M}$ or $1 \mu \mathrm{M}$ had no significant effect on the number of type-III foci and the higher concentrations of $1 \mu \mathrm{M}$ or $10 \mu \mathrm{M}$ reduced it significantly by $56 \%$ for MMC and by $53 \%$ for 5 -FU. The co-treatment with metformin showed the same results as for the single treatment. Only the higher concentrations combined with $1 \mathrm{mM}$ metformin could reduce the number of typeIII foci comparable to the single treatment $(\mathrm{CI}=1.19$ for MMC and 0.95 for 5 -FU) (Fig. 6d+e).

Metformin affects glucose consumption in the BALB-TTM Because metformin alters glucose metabolism in nontransformed BALB/c cells, we measured the glucose concentration in the medium supernatant at different points in time of the BALB-TTM as a first mechanistical analysis. As a control, we cultivated cells without treatment of MCA/TPA so that only a monolayer of nontransformed cells was formed. According to the protocol 
A

Initiation Promotion Therapy

Day: 0

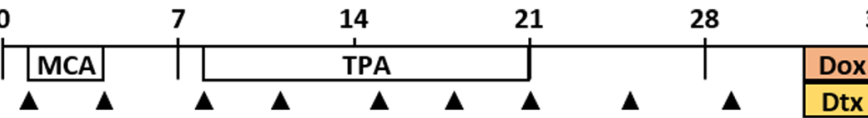

35

\begin{tabular}{|l|}
\hline Dtx \\
\hline \hline $\mathrm{MMC}$ \\
\hline \hline 5-FU \\
\hline
\end{tabular}

Fixation

Giemsa staining

B

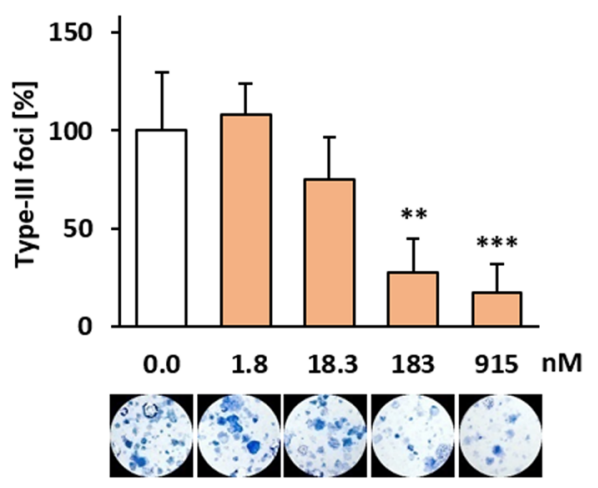

D

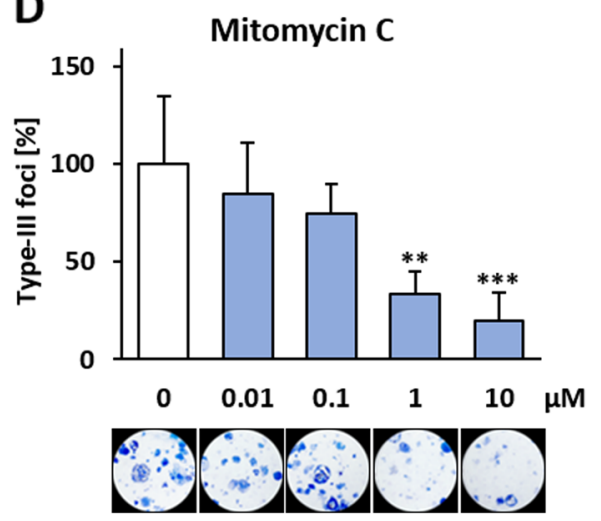

C Docetaxel

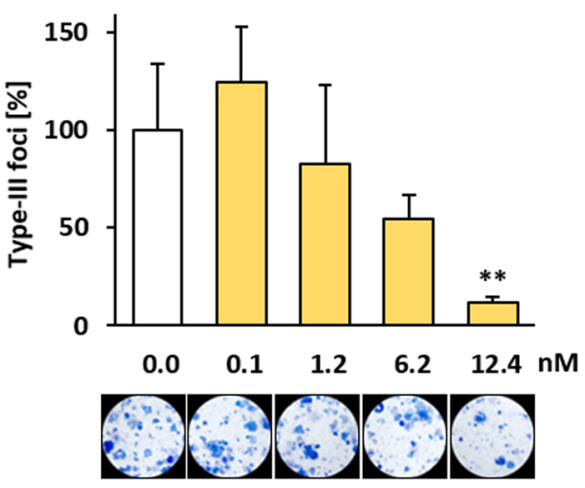

E

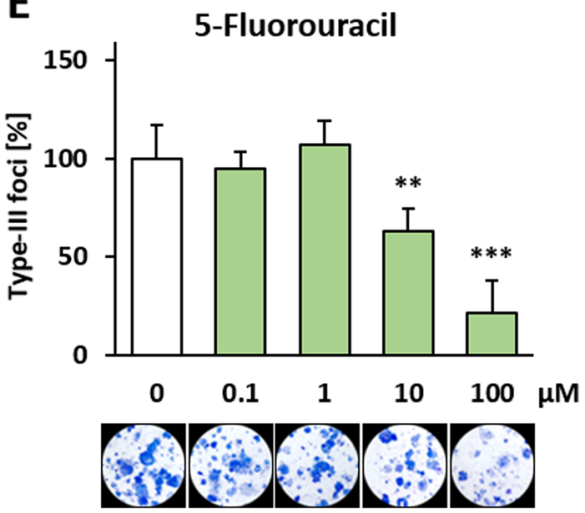

Fig. 4 Establishment of the BALB/C tumor therapy model (BALB-TTM) with chemotherapeutic agents. a The BALB/C 3 T3 cell transformation assay was performed as described earlier. An additional treatment was conducted on day 32 with Doxorubicin (Dox), Doxetaxel (Dtx), Mitomycin C (MMC) or 5-Fluorouracil (5-FU) for $72 \mathrm{~h}$ and cells were fixed on day 35. Representative pictures and the number of type-III foci of 3 biological replicates (mean + SD) are shown for different concentrations of $\mathbf{b}$ Doxorubicin, $\mathbf{c}$ Docetaxel, $\mathbf{d}$ Mitomycin C and e 5-Fluorouracil. Statistical differences were calculated with a one-way ANOVA (post-hoc: Bonferroni or Dunnett-T3) with ${ }^{* *}=(p<0.01)$ and ${ }^{* *}=(p<0.001)$ vs. control

of the BALB-TTM, the cells were treated with metformin on day 32 for $72 \mathrm{~h}$ and the glucose concentration was measured after 24,48 and $72 \mathrm{~h}$. In order to investigate adaptive effects, we further cultivated the cells until day 42 and measured the glucose concentration after 3 or 4 days before fresh medium was added (Fig. 7). Glucose consumption was in the same range in every well before metformin was added with glucose concentrations between 1.66 and $1.75 \mathrm{~g} / \mathrm{l}$ in the DMSO treated cells and 0.97 and $1.01 \mathrm{~g} / \mathrm{l}$ in the MCA-TPA treated cells after 3 days (day 29 to 32 ). As expected, $1 \mathrm{mM}$ and 10 $\mathrm{mM}$ metformin increased glucose consumption significantly in the monolayer cells (day 32-35). Compared to the control cells with $1.60 \mathrm{~g} / \mathrm{l}$ on day 35 , metformin led to glucose concentrations of $1.00 \mathrm{~g} / \mathrm{l}$ and $0.53 \mathrm{~g} / \mathrm{l}$ for 1 $\mathrm{mM}$ and $10 \mathrm{mM}$, respectively. In the MCA-TPA treated cells, where a mixed culture of malignant transformed, foci forming cells and the non-transformed monolayer 
A

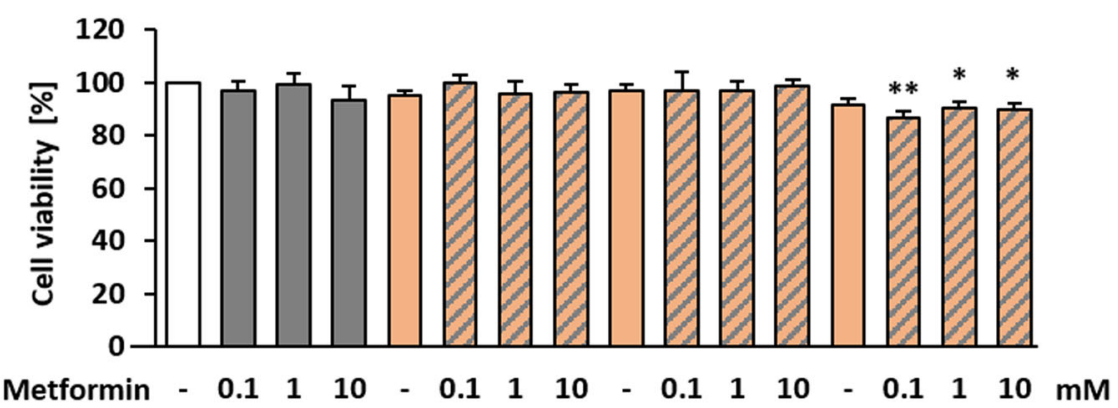

Doxorubicin - - $-1-1 \quad 1 \quad 1 \quad 1 \quad 10101010100100100100$ nM

B

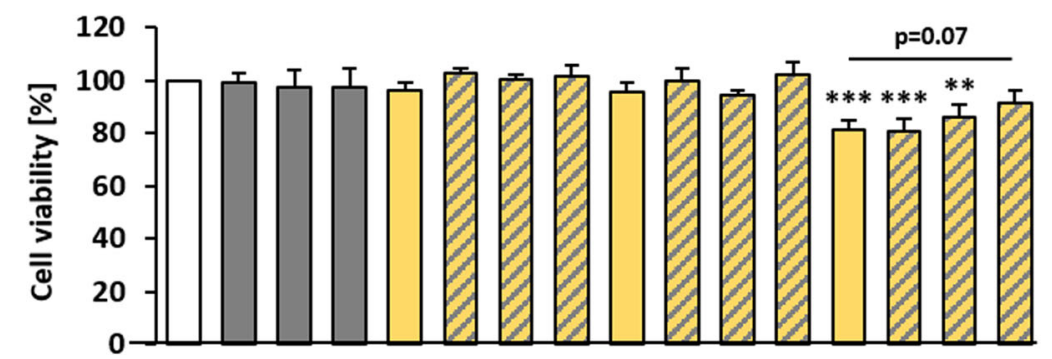

$\begin{array}{llllllllllllllllll}\text { Metformin } & - & 0.1 & 1 & 10 & - & 0.1 & 1 & 10 & - & 0.1 & 1 & 10 & - & 0.1 & 1 & 10 & \mathrm{mM}\end{array}$

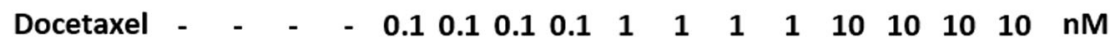

C

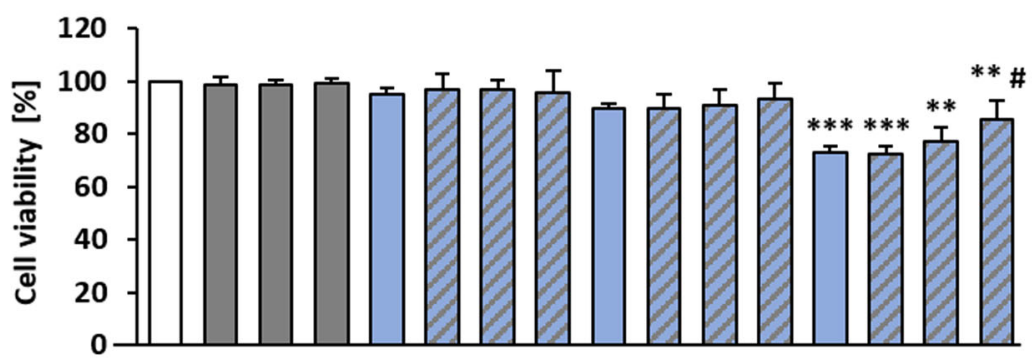

$\begin{array}{llllllllllllllllll}\text { Metformin } & - & 0.1 & 1 & 10 & - & 0.1 & 1 & 10 & - & 0.1 & 1 & 10 & - & 0.1 & 1 & 10 & m M\end{array}$

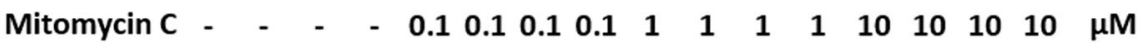

D

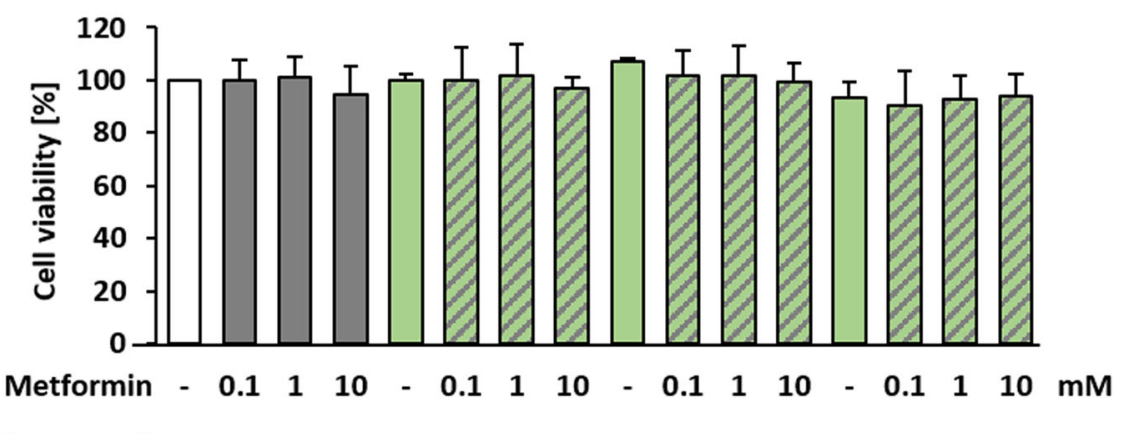

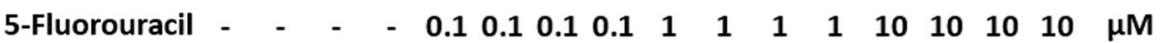

Fig. 5 Cytotoxic effects of chemotherapeutics plus metformin on BALB/c cells. Non-transformed BALB/c cells were seeded in 96 well plates and allowed to grow confluent for $48 \mathrm{~h}$. Afterwards, cells were treated for $24 \mathrm{~h}$ with different concentrations of a Doxorubicin, b Docetaxel, $\mathbf{c}$ Mitomycin C or $\mathbf{d}$ 5-Fluorouracil alone or in combination with different concentrations of metformin. Cell viability was measured indirectly by the reduction of resazurin to fluorescent resorufin. Data are shown as mean + SD of 3 biological replicates. Statistical differences were calculated with a one-way ANOVA (post-hoc: two sided Dunnett-T or Dunnett-T3) with ${ }^{*}=(p<0.05){ }^{* *}=(p<0.01)$ and ${ }^{* * *}=(p<0.001)$ vs. control and \#=(p< 0.05) vs. $10 \mu \mathrm{M}$ Mitomycin C 

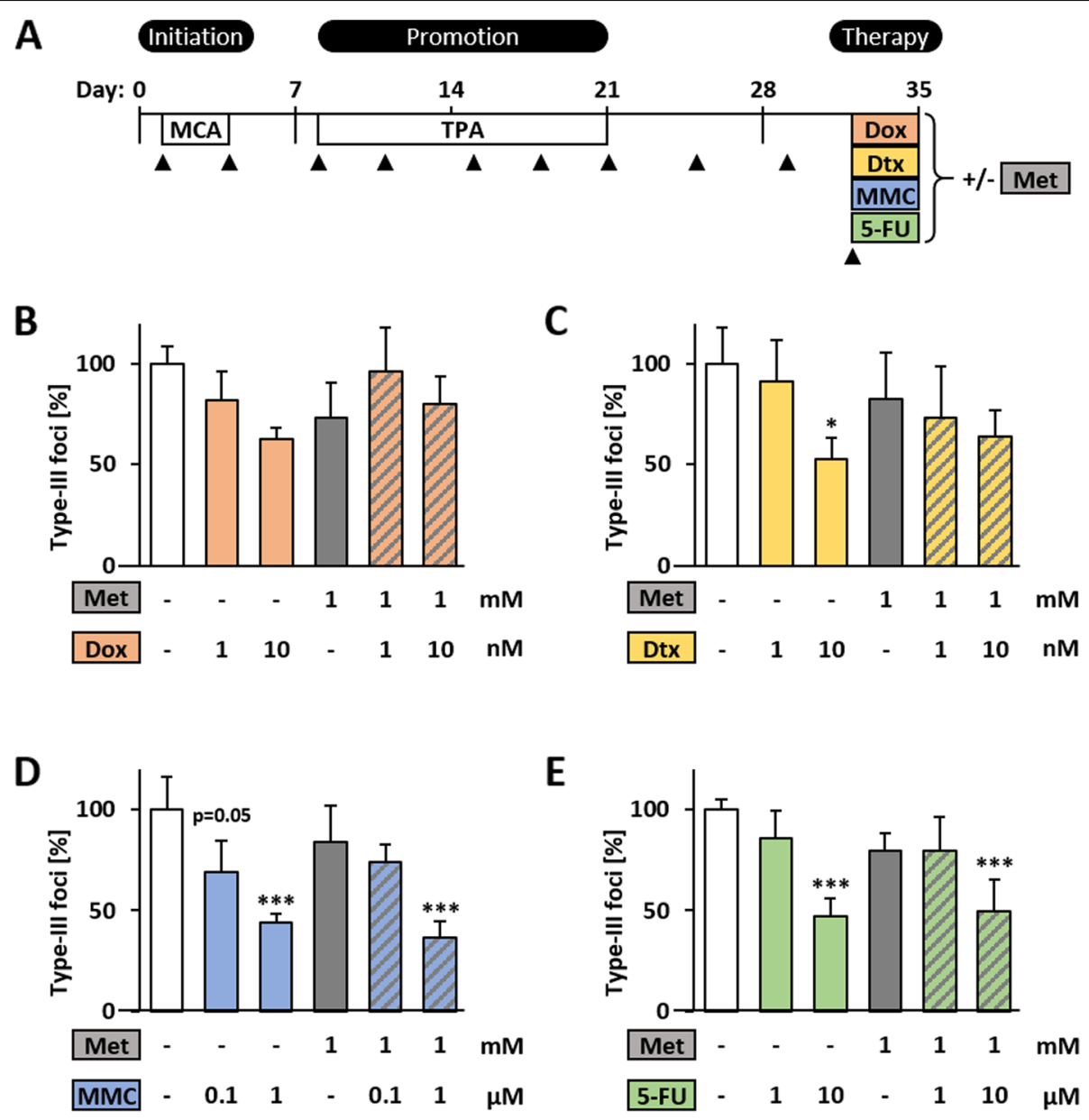

\begin{tabular}{|c|c|c|c|}
\hline MCA & 3-Methylcholanthrene & \begin{tabular}{|l|} 
Dox \\
\end{tabular} & Doxorubicin \\
\hline TPA & Phorbol-12-myristat-13-acetate & Dtx & Docetaxel \\
\hline $\boldsymbol{\Delta}$ & Medium change & MMC & Mitomycin C \\
\hline Met & Metformin & \begin{tabular}{|l|}
$5-F U$ \\
\end{tabular} & 5-Fluorouracil \\
\hline
\end{tabular}

Fig. 6 Combined treatment with chemotherapeutic agents plus metformin in the BALB-TTM. a The BALB/C 3 T3 cell transformation assay was performed as described earlier. An additional treatment was conducted on day 32 with Doxorubicin, Doxetaxel, Mitomycin C or 5-Fluorouracil alone or in combination with metformin for $72 \mathrm{~h}$ and cell were fixed on day 35 . The number of type-lll foci of 4 biological replicates (mean $+\mathrm{SD}$ ) are shown for different concentrations of $\mathbf{b}$ Doxorubicin, $\mathbf{c}$ Docetaxel, d Mitomycin C and e 5-Fluorouracil in combination with $1 \mathrm{mM}$ metformin. Statistical differences were calculated with a one-way ANOVA (post-hoc: Bonferroni) with ${ }^{*}=(p<0.05)$ and ${ }^{* *}=(p<0.001)$ vs. control

cells exists, metformin again increased glucose consumption significantly at a concentration of $10 \mathrm{mM}$ reaching saturation on day 35. Compared to the control cells with $1.16 \mathrm{~g} / \mathrm{l}$ on day 34 , metformin led to glucose concentrations of $0.78 \mathrm{~g} / \mathrm{l}$ and $0.34 \mathrm{~g} / \mathrm{l}$ for $1 \mathrm{mM}$ and 10 $\mathrm{mM}$, respectively. An adaptive effect was observed for $10 \mathrm{mM}$ metformin in the non-transformed monolayer cells where glucose consumption was increased also on day 38 when cells were no longer treated with metformin. In the mixed culture of non-transformed and malignant transformed cells, $10 \mathrm{mM}$ metformin decreased the glucose concentration to a minimum after $72 \mathrm{~h}$. Probably, the lacking glucose in the medium induced cell death and finally stops glucose consumption, leading to a stable glucose concentration in the medium from day 35-42 (Fig. 7).

\section{Discussion}

In the present study, we modified the well-known BALB-CTA by adding an additional treatment on day 32 for $72 \mathrm{~h}$ in order to establish an in vitro tumor therapy model, the BALB-TTM. The effectiveness was proven 


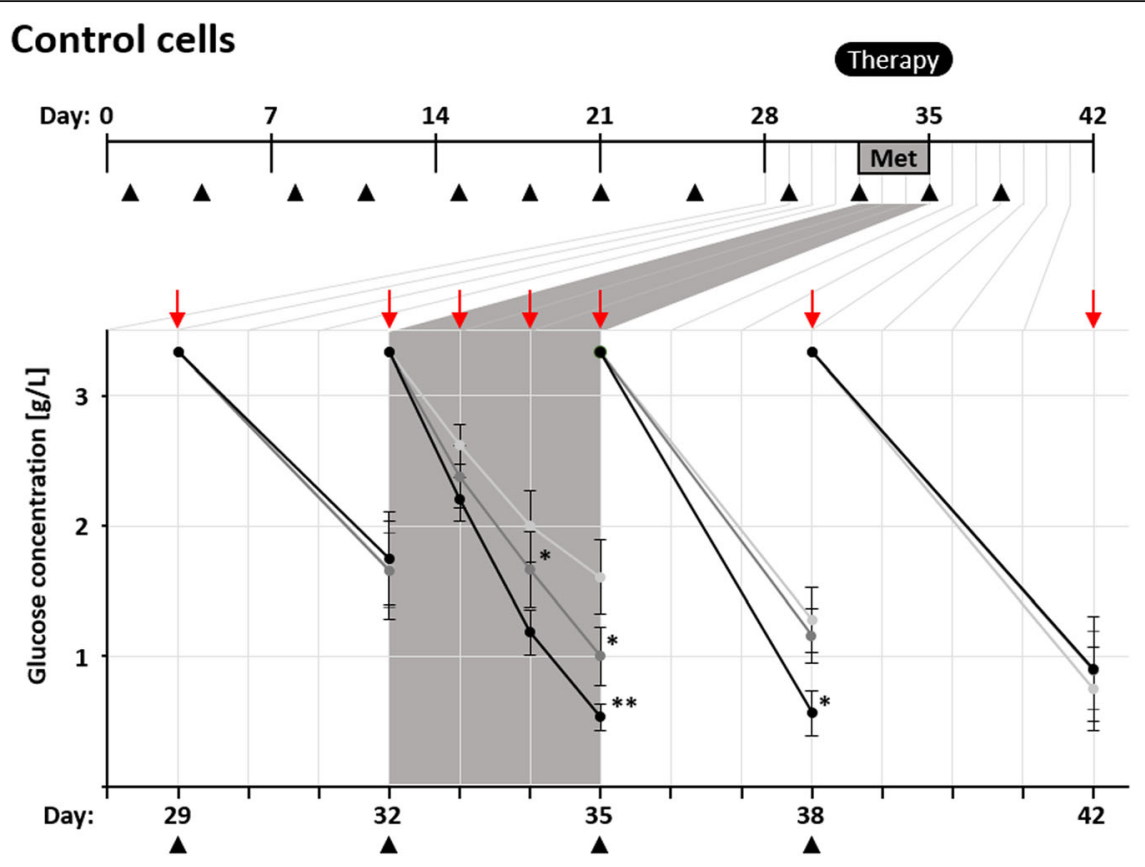

MCA/TPA treated cells
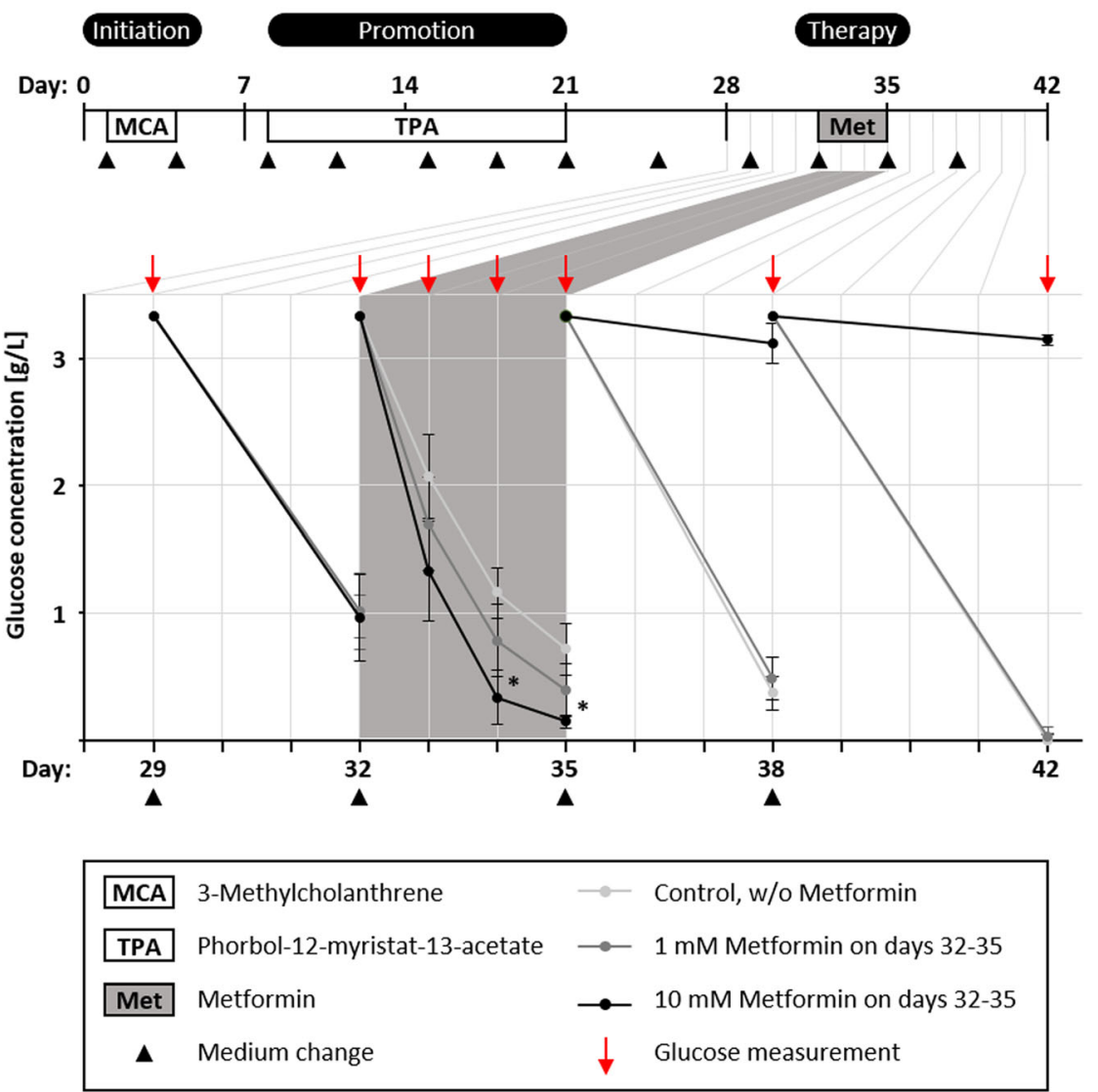

Fig. 7 (See legend on next page.) 
(See figure on previous page.)

Fig. 7 Metformin alters glucose consumption in the BALB-TTM. The BALB/c 3 T3 cell transformation assay was performed as described earlier. An additional treatment was conducted from day 32-35 with metformin. On day 35 and 38, fresh medium without metformin was added again.

Control cells were not treated with MCA/TPA. Medium supernatant was collected at day 32, 33, 34, 35,38 and 42 and glucose concentration was measured. The slanting lines indicate the decrease of glucose after fresh medium with $3.15 \mathrm{~g} / \mathrm{l} \mathrm{D}$-glucose was added every $3-4$ days. Statistical differences were calculated with a one-way ANOVA (post-hoc: Bonferroni) with ${ }^{*}=(p<0.05)$ and ${ }^{* *}=(p<0.01)$ vs. control for each point in time

successfully with 4 well-established chemotherapeutic agents and furthermore, for the very first time, a combined treatment with metformin was tested. The results are surprising as they show that metformin could partly mitigate the effects of the chemotherapeutic agents and a deregulated glucose metabolism seems to be involved in this process.

In vitro cell transformation assays mimic different phases of the in vivo multi-step carcinogenesis process. They are used by chemical, cosmetic and pharmaceutical industries for more than 6 decades to screen agents for carcinogenicity [35]. We have shown previously that the BALB-CTA is also combinable with different molecular biologic and biochemical methods, thus allowing to screen for molecular mechanisms [27, 28]. In this case, the malignant cell transformation is induced by treatment with the tumor initiator MCA following the tumor promotor TPA. Consequently, transformed cells lose their contact inhibition, start to grow over the monolayer of non-transformed BALB/c cells and pile up to characteristic, multilayered cell foci. For the BALBTTM, an additional therapeutic treatment was performed on day 32 for $72 \mathrm{~h}$ on already existing cell foci. A reduction of the number of type-III foci could hence indicate a chemotherapeutic potential of the tested substance. Compared to rodent studies, this assay is less time consuming, needs a lower amount of resources and has no ethical implications. Moreover, molecular modes of action could be investigated easily, standardized and compared between non-transformed and malignant transformed cells.

The anticancer effects of metformin are widely described in vitro and in vivo [36] and now, were also confirmed in the BALB-CTA. Comparable to diabetic patients who show lower incidences for developing cancer when taking metformin for years [3, 37], chronical treatment with $1 \mathrm{mM}$ metformin decreases number of type-III foci significantly and shows a tumor preventive effect. At this point, the BALB-CTA offers a strong tool for further mechanistic studies. Moreover, when metformin was added in the late phase of the BALB-CTA on already existing cell foci, a chemotherapeutic effect was observed with a significant decrease in number of typeIII foci. Although plasma concentrations of metformin in diabetic patients are in the lower range of 10 to $40 \mu \mathrm{M}$ [38], it was shown that metformin accumulates highly in tissues of mice, especially in the gastrointestinal tract where concentrations were up to 50 times higher compared to plasma but also declined to less than $2 \%$ of the maximum after 24h [39]. Plasma concentrations of $500 \mu \mathrm{M}$ can be reached in mice when metformin is administered by i.p. injection. In this case, metformin further accumulates in liver and kidney and reaches millimolar concentrations. Although the retention in tumors was much lower, the i.p. administration could be a promising approach for tumor patients [40]. In addition, the use of milimolar concentrations of metformin for in vitro assays seems to be relevant, as other nutrients like serine are available in supraphysiological concentrations in the medium that are known to reduce metformin sensitivity [41].

Despite the anticancer effects of metformin, its application as an adjuvant in tumor therapy offers conflicting results. Therefore, we established an in vitro tumor therapy model in order to investigate interactions between metformin and several chemotherapeutic agents. First, the applicability of the new BALB-TTM was proven successfully with four chemotherapeutic agents from different classes. In this case, treatment for $72 \mathrm{~h}$ was sufficient to decrease the number of type-III foci significantly even in non-toxic concentrations for Dtx, MMC and 5-FU. Such an effect was observed for Dox only in toxic concentrations. Second, the combined therapy with metformin was tested. An evidence for the cytoprotective role of metformin was given already via the Resazurin assay as metformin could mitigate the cytotoxic effects of Dtx and MMC. In the BALB-TTM, such an chemoresistanceinducing effect was shown for Dox and Dtx. In various in vitro and in vivo studies metformin was shown to decrease Dox-induced cardiotoxicity and is considered as a promising approach for patients treating with Dox [19]. Moreover, metformin could not only reduce the therapeutic concentration of Dox and diminish cardiotoxic side effects, but also shows synergistic anti-tumor effects for prostate [42] and breast cancer [19, 43-47] in different cell and mouse models. However, in the present study metformin could not improve the anticancer effects of Dox in the BALB-TTM. To the contrary, the number of type-III foci increased slightly but not significantly. Consequently, the therapeutic effect seems to be highly dependent on the type of tumor. For metastatic castration-resistant prostate cancer, Dtx is the first-line chemotherapeutic agent. Since the treatment is associated with considerable toxic side effects, 
there is a need for chemosensitizing agents and it was shown that metformin is able to improve the prognosis [48]. However, in vitro studies with different prostate cancer cell lines treated with metformin and Dtx demonstate controversial results [20,49]. A clinical study regarding the combined effect of Dtx with metformin in patients with castration-resistant prostate cancer showed that metformin did not act as an chemosensitizer and could not improve prostate cancer specific or overall survival [50]. In our study, metformin even offers reverse results as the therapeutic, focireducing effect in the BALB-TTM is mitigated. Taken together, the potential role for metformin in prostate cancer therapy remains controversial and seems to be dependent on many individual factors. Thereby, the BALB-TTM offers a potent tool to elucidate the molecular interactions between Dtx and metformin.

In order to explain our observed effects of the combined therapy with MMC and metformin, we have focused on glucose metabolism. A deregulated energy metabolism in general is characteristic for several tumor cells and especially the glucose metabolism seems to be a promising target for cancer therapy [51]. MMC is a DNA cross linker that requires reductive activation (bioreduction) to exert its chemotherapeutic effects [52]. As mentioned elsewhere [53], an enhanced glycolytic rate results in higher $\mathrm{NAD}(\mathrm{P}) \mathrm{H}$ and thiol levels. Consequently, the induced intracellular reducing environment is able to facilitate the bioreduction of MMC. The effect of metformin on energy metabolism varies highly depending on the cell type and status of transformation. Therefore, we investigated the impact of metformin on glucose consumption and AMPK activation in nontransformed BALB/c fibroblasts first. In line with the observed effect in muscle cells [9] and podocytes [8], metformin increases the glucose consumption in the BALB/ c cells dose-dependently. However, even when glucose concentration reaches a minimum of $0.5 \mathrm{~g} / \mathrm{l}$, the AMPK becomes not activated. Therefore, metformin seems to impair glucose metabolism in the utilized cell line without affecting the cellular energy sensor AMPK.

Due to the observed increase in glucose consumption, we have expected a synergistic effect of metformin and MMC in the BALB-TTM. Despite the higher glycolytic rate, metformin induced resistance to MMC in our studies. Indeed, a higher glucose consumption after metformin treatment is described only for healthy, peripheral tissue $[8,9]$. For cancer cells, a converse effect with lower glucose consumption after metformin treatment was shown that is further described as an inhibition of the Warburg effect [12-16]. Therefore, we measured glucose consumption during the BALB-TTM in nontransformed monolayer cells and in the mixed population with cell foci of malignant transformed cells. As expected, we observed an increased consumption after metformin treatment in non-transformed cells but surprisingly, this was also the case in the mixed population. In fact, the MCA/TPA treated cells show even a higher glucose consumption compared to the non-transformed monolayer cells. At this point, a major limiting factor is the co-existence of non-transformed BALB/c monolayer cells and the malignant transformed, foci forming cells. Thus, we cannot precisely investigate the specific effect of metformin on the malignant transformed cells and have to consider, that the increase in glucose consumption is only due to the non-transformed monolayer cells. Possibly, metformin did not increase glycolysis in malignant transformed cells of the BALB-TTM and therefore did not enhance the therapeutic effect of MMC. In order to clarify the specific effects of metformin on malignant transformed cells in the BALB-TTM, investigations in isolated malignant transformed cells are strongly necessary.

\section{Conclusion}

In conclusion, we have established an in vitro tumor therapy model that offers a helpful tool for investigating molecular mechanisms of tumor therapeutic drugs. In this model, metformin as an adjuvant mitigated the chemotherapeutic effects of Dox and Dtx. Mechanistically, an increase in glucose consumption after metformin treatment was observed but a major limiting factor for clarifying cell specific mechanisms remains the coexistence of non-transformed and malignant transformed cells on the same plate. Finally, this paper indicates a cautious use of metformin during chemotherapy.

\section{Abbreviations}

5-FU: 5-Fluorouracil; AMPK: 5' AMP-activated protein kinase; BALB-CTA: BALB/ c cell transformation assay; BALB-TTM: BALB/c tumor therapy model;

Cl: Combination Index; Dox: Doxorubicin; Dtx: Docetaxel; MCA: 3methylcholanthrene; MMC: Mitomycin C; TPA: 12-tetradecanoylphorbol-13acetate

\section{Supplementary Information}

The online version contains supplementary material available at https://doi. org/10.1186/s12885-021-08354-X

Additional file 1: Supplementary Figure 1. Densitometric analysis of Western Blot results exemplary shown in Fig. 1b. Data are shown as mean + standard error of 3 independent experiments, normalized to aTubulin and shown relatively to the $24 \mathrm{~h}$ control. Densitometric analysis was performed using the software ImageJ $1.48 \mathrm{~V}$.

Additional file 2: Supplementary Figure 2. Original Western Blots used for Fig. 1b. Proteins were extracted and protein expression as well as phosphorylation levels of AMPK at Thr172 were detected via immunoblot in 3 biological replicates. After detection of $\mathrm{p}$-AMPK, the membrane was stripped two times and re-probed with AMPK MAB and $a$-Tubulin $m A B$ to confirm equal loading. The red boxes indicate the cropped regions used in the representative figures.

Acknowledgements

We thank Annett Müller for her excellent technical assistance during the whole project. 


\section{Authors' contributions}

$\mathrm{FM}, \mathrm{DH}$, and RT designed the experiments and interpreted the data. FM, SG, SS and $\mathrm{CL}$ performed the experiments. FM wrote the manuscript. The authors read and approved the final manuscript.

\section{Funding}

Open Access funding enabled and organized by Projekt DEAL.

\section{Availability of data and materials}

The datasets used and/or analysed during the current study are available from the corresponding author on reasonable request.

\section{Declarations}

Ethics approval and consent to participate

Not applicable.

\section{Consent for publication}

Not applicable.

\section{Competing interests}

The authors declare that they have no competing interests.

\section{Received: 7 December 2020 Accepted: 10 May 2021}

\section{Published online: 28 May 2021}

\section{References}

1. Cancer. https://www.who.int/news-room/fact-sheets/detail/cancer. Accessed 04 Nov 2020.

2. Mokhtari RB, Homayouni TS, Baluch N, Morgatskaya E, Kumar S, Das B, et al. Combination therapy in combating cancer. Oncotarget. 2017;8(23):3802243. https://doi.org/10.18632/oncotarget.16723.

3. Evans JMM, Donnelly LA, Emslie-Smith AM, Alessi DR, Morris AD. Metformin and reduced risk of cancer in diabetic patients. Brit Med J. 2005;330(7503): 1304-5. https://doi.org/10.1136/bmj.38415.708634.F7.

4. Pecinova A, Brazdova A, Drahota Z, Houstek J, Mracek T. Mitochondrial targets of metformin - are they physiologically relevant? Biofactors. 2019; 45(5):703-11. https://doi.org/10.1002/biof.1548.

5. Meng SM, Cao J, He QY, Xiong LS, Chang E, Radovick S, et al. Metformin activates AMP-activated protein kinase by promoting formation of the alpha beta gamma Heterotrimeric complex. J Biol Chem. 2015;290(6):3793-802. https://doi.org/10.1074/jbc.M114.604421

6. Zhou G, Myers R, Li Y, Chen Y, Shen X, Fenyk-Melody J, et al. Role of AMPactivated protein kinase in mechanism of metformin action. J Clin Invest. 2001;108(8):1167-74. https://doi.org/10.1172/JCl13505.

7. Inzucchi SE, Maggs DG, Spollett GR, Page SL, Rife FS, Walton V, et al. Efficacy and metabolic effects of metformin and troglitazone in type II diabetes mellitus. N Engl J Med. 1998;338(13):867-72. https://doi.org/10.1056/NEJM1 99803263381303.

8. Polianskyte-Prause Z, Tolvanen TA, Lindfors S, Dumont V, Van M, Wang H, et al. Metformin increases glucose uptake and acts renoprotectively by reducing SHIP2 activity. FASEB J. 2019;33(2):2858-69. https://doi.org/10.1 096/fj.201800529RR.

9. Sajan MP, Bandyopadhyay G, Miura A, Standaert ML, Nimal S, Longnus SL, et al. AICAR and metformin, but not exercise, increase muscle glucose transport through AMPK-, ERK-, and PDK1-dependent activation of atypical PKC. Am J Physiol-Endoc M. 2010;298(2):E179-E92.

10. Seshasai SRK, Kaptoge S, Thompson A, Di Angelantonio E, Gao P, Sarwar N, et al. Diabetes mellitus, fasting glucose, and risk of cause-specific death. N Engl J Med. 2011;364(9):829-41.

11. Boyd DB. Insulin and cancer. Integr Cancer Ther. 2003;2(4):315-29. https:// doi.org/10.1177/1534735403259152

12. Salani B, Marini C, Rio AD, Ravera S, Massollo M, Orengo AM, et al. Metformin impairs glucose consumption and survival in Calu- 1 cells by direct inhibition of hexokinase-Il. Sci Rep. 2013;3(1). https://doi.org/10.1038/ srep02070.

13. Marini C, Salani B, Massollo M, Amaro A, Esposito Al, Orengo AM, et al. Direct inhibition of hexokinase activity by metformin at least partially impairs glucose metabolism and tumor growth in experimental breast cancer. Cell Cycle. 2013;12(22):3490-9. https://doi.org/10.4161/cc.26461.
14. Jia YL, Ma ZY, Liu XF, Zhou WJ, He S, Xu X, et al. Metformin prevents DMHinduced colorectal cancer in diabetic rats by reversing the Warburg effect. Cancer Med-Us. 2015;4(11):1730-41. https://doi.org/10.1002/cam4.521.

15. Harada K, Ferdous T, Harada T, Ueyama Y. Metformin in combination with 5-fluorouracil suppresses tumor growth by inhibiting the Warburg effect in human oral squamous cell carcinoma. Int J Oncol. 2016;49(1):276-84. https://doi.org/10.3892/ijo.2016.3523.

16. Tang DH, Xu L, Zhang MM, Dorfman RG, Pan YD, Zhou Q, et al. Metformin facilitates BG45-induced apoptosis via an anti-Warburg effect in cholangiocarcinoma cells. Oncol Rep. 2018;39(4):1957-65. https://doi.org/1 0.3892/or.2018.6275

17. Coyle C, Cafferty FH, Vale C, Langley RE. Metformin as an adjuvant treatment for cancer: a systematic review and meta-analysis. Ann Oncol. 2016;27(12):2184-95. https://doi.org/10.1093/annonc/mdw410.

18. Franciosi M, Lucisano G, Lapice E, Strippoli GFM, Pellegrini F, Nicolucci A Metformin therapy and risk of cancer in patients with type 2 diabetes: systematic review. PloS one. 2013:8(8):1-12.

19. Ajzashokouhi AH, Bostan HB, Jomezadeh V, Hayes AW, Karimi G. A review on the cardioprotective mechanisms of metformin against doxorubicin. Hum Exp Toxicol. 2020;39(3):237-48. https://doi.org/10.1177/096032711 9888277.

20. Biernacka KM, Persad RA, Bahl A, Gillatt D, Holly JMP, Perks CM. Hyperglycaemia-induced resistance to Docetaxel is negated by metformin: a role for IGFBP-2. Endocr Relat Cancer. 2017;24(1):17-30. https://doi.org/1 0.1530/ERC-16-0095

21. Coperchini F, Leporati P, Rotondi M, Chiovato L. Expanding the therapeutic spectrum of metformin: from diabetes to cancer. J Endocrinol Investig. 2015;38(10):1047-55. https://doi.org/10.1007/s40618-015-0370-z.

22. Zhang Y, Feng XL, Li T, Yi EP, Li Y. Metformin synergistic pemetrexed suppresses non-small-cell lung cancer cell proliferation and invasion in vitro. Cancer Med-Us. 2017;6(8):1965-75. https://doi.org/10.1002/cam4.1133.

23. Zi FM, He JS, Li Y, Wu C, Yang L, Yang Y, et al. Metformin displays antimyeloma activity and synergistic effect with dexamethasone in in vitro and in vivo xenograft models. Cancer Lett. 2015:356(2 Pt B):443-53.

24. Moro M, Caiola E, Ganzinelli M, Zulato E, Rulli E, Marabese M, et al Metformin enhances cisplatin-induced apoptosis and prevents resistance to cisplatin in co-mutated KRAS/LKB1 NSCLC. J Thorac Oncol. 2018;13(11): 1692-704. https://doi.org/10.1016/j.jtho.2018.07.102.

25. Janjetovic K, Vucicevic L, Misirkic M, Vilimanovich U, Tovilovic G, Zogovic N, et al. Metformin reduces cisplatin-mediated apoptotic death of cancer cells through AMPK-independent activation of Akt. Eur J Pharmacol. 2011;651(13):41-50. https://doi.org/10.1016/j.ejphar.2010.11.005.

26. Damelin LH, Jivan R, Veale RB, Rousseau AL, Mavri-Damelin D. Metformin induces an intracellular reductive state that protects oesophageal squamous cell carcinoma cells against cisplatin but not copperbis(thiosemicarbazones). BMC Cancer. 2014;14:1-11.

27. Poburski D, Thierbach R. Improvement of the BALB/C-3T3 cell transformation assay: a tool for investigating cancer mechanisms and therapies. Sci Rep. 2016;6(1):1-8.

28. Poburski D, Leovsky C, Boerner JB, Szimmtenings L, Ristow M, Glei M, et al. Insulin-IGF signaling affects cell transformation in the BALB/c $3 T 3$ cell model. Sci Rep. 2016;6(1):1-12.

29. Sasaki K, Bohnenberger S, Hayashi K, Kunkelmann T, Muramatsu D, Phrakonkham P, et al. Recommended protocol for the BALB/c 3T3 cell transformation assay. Mutat Res. 2012;744(1):30-5. https://doi.org/10.1016/j. mrgentox.2011.12.014.

30. Sasaki K, Bohnenberger S, Hayashi K, Kunkelmann T, Muramatsu D, Poth A, et al. Photo catalogue for the classification of foci in the BALB/C $3 T 3$ cell transformation assay. Mutat Res. 2012;744(1):42-53. https://doi.org/10.1016/j. mrgentox.2012.01.009

31. Bradford MM. A rapid and sensitive method for the quantitation of microgram quantities of protein utilizing the principle of protein-dye binding. Anal Biochem. 1976;72(1-2):248-54. https://doi.org/10.1016/0003-2 697(76)90527-3.

32. Glass GV, Peckham PD, Sanders JR. Consequences of failure to meet assumptions underlying fixed effects analyses of variance and covariance. Rev Educ Res. 1972;42(3):237-88. https://doi.org/10.3102/00346543042003237.

33. Harwell MR, Rubinstein EN, Hayes WS, Olds CC. Summarizing Monte-Carlo results in methodological research - the 1-factor and 2-factor fixed effects Anova cases. J Educ Stat. 1992:17(4):315-39. https://doi.org/10.3102/1 0769986017004315 
34. Foucquier J, Guedj M. Analysis of drug combinations: current methodological landscape. Pharma Res Per. 2015;3(3):e00149. https://doi. org/10.1002/prp2.149.

35. Vanparys P, Corvi R, Aardema MJ, Gribaldo L, Hayashi M, Hoffmann S, et al. Application of in vitro cell transformation assays in regulatory toxicology for pharmaceuticals, chemicals, food products and cosmetics. Mutat Res-Gen Tox En. 2012;744(1):111-6. https://doi.org/10.1016/j.mrgentox.2012.02.001.

36. Zhao B, Luo J, Yu T, Zhou L, Lv H, Shang P. Anticancer mechanisms of metformin: a review of the current evidence. Life Sci. 2020;254:117717. https://doi.org/10.1016/j.lfs.2020.117717.

37. Zhang K, Bai P, Dai H, Deng Z. Metformin and risk of cancer among patients with type 2 diabetes mellitus: a systematic review and meta-analysis. Prim Care Diabetes. 2020;43(7):1650-8. https://doi.org/10.2337/dc19-1708.

38. Stocker SL, Morrissey KM, Yee SW, Castro RA, Xu L, Dahlin A, et al. The effect of novel promoter variants in MATE1 and MATE2 on the pharmacokinetics and pharmacodynamics of metformin. Clin Pharmacol Ther. 2013;93(2):18694. https://doi.org/10.1038/clpt.2012.210

39. Wilcock C, Bailey CJ. Accumulation of metformin by tissues of the normal and diabetic mouse. Xenobiotica. 1994;24(1):49-57. https://doi.org/10.3109/ 00498259409043220

40. Iversen AB, Horsman MR, Jakobsen S, Jensen JB, Garm C, Jessen N, et al. Results from C-11-metformin-PET scans, tissue analysis and cellular drugsensitivity assays questions the view that biguanides affects tumor respiration directly. Sci Rep-UK. 2017;7:1-13.

41. Gravel SP, Hulea L, Toban N, Birman E, Blouin MJ, Zakikhani M, et al. Serine deprivation enhances antineoplastic activity of biguanides. Cancer Res. 2014;74(24):7521-33. https://doi.org/10.1158/0008-5472.CAN-14-2643-T.

42. Shafa MH, Jalal R, Kosari N, Rahmani F. Efficacy of metformin in mediating cellular uptake and inducing apoptosis activity of doxorubicin. Regul Toxicol Pharmacol. 2018;99:200-12. https://doi.org/10.1016/j.yrtph.2018.09.023.

43. Kwon YS, Chun SY, Nan HY, Nam KS, Lee C, Kim S. Metformin selectively targets $4 \mathrm{~T} 1$ tumorspheres and enhances the antitumor effects of doxorubicin by downregulating the AKT and STAT3 signaling pathways. Oncol Lett. 2019;17(2):2523-30. https://doi.org/10.3892/ol.2018.9827.

44. Li Y, Luo J, Lin MT, Zhi P, Guo WW, You J, et al. Co-delivery of metformin enhances the antimultidrug resistant tumor effect of doxorubicin by improving hypoxic tumor microenvironment. Mol Pharm. 2019;16(7):296679. https://doi.org/10.1021/acs.molpharmaceut.9b00199.

45. Li Y, Wang M, Zhi P, You J, Gao JQ. Metformin synergistically suppress tumor growth with doxorubicin and reverse drug resistance by inhibiting the expression and function of P-glycoprotein in MCF7/ADR cells and xenograft models. Oncotarget. 2018;9(2):2158-74. https:/doi.org/10.18632/oncotarget.23187.

46. Marinello PC, Pannis C, Silva TNX, Binato R, Abdelhay E, Rodrigues JA, et al. Metformin prevention of doxorubicin resistance in MCF-7 and MDA-MB-231 involves oxidative stress generation and modulation of cell adaptation genes. Sci Rep. 2019;9(1):5864. https://doi.org/10.1038/s41598-019-42357-w.

47. Hiopoulos D, Hirsch HA, Struhl K. Metformin decreases the dose of chemotherapy for prolonging tumor remission in mouse xenografts involving multiple cancer cell types. Cancer Res. 2011;71(9):3196-201. https://doi.org/10.1158/0008-5472.CAN-10-3471.

48. He K, Hu H, Ye S, Wang H, Cui R, Yi L. The effect of metformin therapy on incidence and prognosis in prostate cancer: a systematic review and metaanalysis. Sci Rep. 2019:9(1):2218. https://doi.org/10.1038/s41598-018-38285-w.

49. Mayer MJ, Klotz LH, Venkateswaran V. Evaluating metformin as a potential chemosensitizing agent when combined with docetaxel chemotherapy in castration-resistant prostate cancer cells. Anticancer Res. 2017;37(12):6601-7. https://doi.org/10.21873/anticanres.12117.

50. Mayer MJ, Klotz LH, Venkateswaran V. The effect of metformin use during docetaxel chemotherapy on prostate cancer specific and overall survival of diabetic patients with castration resistant prostate cancer. J Urol. 2017; 197(4):1068-74. https://doi.org/10.1016/j.juro.2016.10.069.

51. Hay N. Reprogramming glucose metabolism in cancer: can it be exploited for cancer therapy? Nat Rev Cancer. 2016;16(10):635-49. https://doi.org/10.1 038/nrc.2016.77.

52. Paz MM. Reductive activation of mitomycin C by thiols: kinetics, mechanism, and biological implications. Chem Res Toxicol. 2009;22(10):1663-8. https:// doi.org/10.1021/tx9002758

53. Damelin LH, Jivan R, Veale RB, Rousseau AL, Mavri-Damelin D. Metformin induces an intracellular reductive state that protects oesophageal squamous cell carcinoma cells against cisplatin but not copperbis(thiosemicarbazones). BMC Cancer. 2014;14:314.

\section{Publisher's Note}

Springer Nature remains neutral with regard to jurisdictional claims in published maps and institutional affiliations.
Ready to submit your research? Choose BMC and benefit from:

- fast, convenient online submission

- thorough peer review by experienced researchers in your field

- rapid publication on acceptance

- support for research data, including large and complex data types

- gold Open Access which fosters wider collaboration and increased citations

- maximum visibility for your research: over $100 \mathrm{M}$ website views per year

At BMC, research is always in progress.

Learn more biomedcentral.com/submissions 